\title{
„A może jednak wątpię w tę wojnę, tak samo jak wątpię w istnienie wielkich gadów? [...]” Świat (p)o wojnie w poezji Tomasza Pietrzaka
}

W sferze imaginacji naznaczenie jest utrwaleniem doświadczenia szczególnego rodzaju. Może wynikać z osobistych przeżyć lub stać się częścią egzystencji potomków, niezależnie od woli i wyborów osób, których dotyczy. Piętno przypomina o sobie permanentnie, niejednokrotnie prowadzi do pragnienia odrzucenia ciężaru przeszłości. Barbara Skarga w książce Ślad i obecność zwraca uwagę na naznaczenie jako formę „zmazy”, która:

Pojawia się [...] na skutek jakiegoś wydarzenia lub okoliczności, najczęściej niezależnych od nas i niekoniecznie wciągających nas w swój krąg, ale jakoś dotykających, wywierających wpływ. Niekiedy bezwolnie w nich uczestniczymy, zwłaszcza wówczas, gdy zakres tych wydarzeń jest szeroki. Bywa, że się $\mathrm{w}$ nie świadomie angażujemy, lub przeciwnie, trzymamy się z dala, nie chcąc mieć z nimi nic wspólnego. Czy się im poddajemy, czy staramy się zamknąć we własnym świecie, w momencie gdy zaczynają się zazębiać z tym, co nam bliskie, nie możemy przejść wobec nich obojętnie. Ich oddziaływanie kładzie cień na naszym życiü.

Opisywany przez Skargę ślad w przypadku podmiotu wierszy ostatniego tomu Tomasza Pietrzaka pt. Pospół wiąże się nierozerwalnie z pamięcią o wojnie. Urodzony w 1982 roku w Siemianowicach Śląskich poeta zadebiutował w 2006 roku arkuszem poetyckim zatytułowanym Zaklinanie chwil. Od tamtego

\footnotetext{
${ }^{1}$ B. SKarga: Ślad i obecność. Warszawa 2002, s. 83.
} 
czasu opublikował cztery zbiory liryków², których głównym tematem stała się miniona śląska codzienność, zastygła $\mathrm{w}$ kadrach starych fotografii oraz zapisana w dziełach sztuki. Motyw przeszłości, obecnej między innymi w genach wszelkich stworzeń, wielokrotnie będzie powracać w twórczości Pietrzaka. $\mathrm{W}$ jego najnowszej książce śląskie wątki zostały skorelowane z tematem Zagłady, co wyraźnie odzwierciedla się we wszystkich wierszach. To szczególny zbiór, w którym pamięć o wojnie staje się bliska między innymi ze względu na przekazywanie śladów rodzinnych historii kolejnym pokoleniom. Naznaczenie jest zatem związane z przekonaniem, że okruchy (nie)minionej Zagłady nieprzerwanie istnieją w rzeczywistości, widoczne w napięciach społecznych i psychicznych, a nade wszystko $\mathrm{w}$ problemach związanych $\mathrm{z}$ próbami integracji wspomnień wydarzeń granicznych. W tomie Pietrzaka ujawnia się to, co wspólne nie tylko mieszkańcom Europy Środkowej, lecz szczególnie dotyczy bliskiego autorowi Śląska. Długo tłumiona pamięć, związana $\mathrm{z}$ historią tego regionu, zostaje więc wpisana w sieć splecionych $\mathrm{z}$ sobą fantazmatów.

W poezji Pietrzaka owo uwikłanie w rzeczywistość wojenną prowadzi powojennego bohatera do konfrontacji z wydarzeniem, które nie było jedynie przekazane, ale jakimś sposobem zostało wpisane w jego egzystencję: „,...] Chciałbym już nie żyć / życiem babek. Pora je wykadzić, / i wypędzić z siebie, wyksztusić3 , / co zalęgło się w ciele; już czas / zluzować dom, zrobić miejsce / nowemu [...]”. Interesujące, że próba zerwania z pozornie minionym wiąże się jednocześnie z przekonaniem, że wysiłek zapomnienia otwiera jedynie miejsce na zastąpienie jednej wojny inną, która nieuchronnie nadejdzie: „Nim przyjdzie nowa wojna / pozbądźmy się resztek starej / [...]"5. Podmiot tym samym sugeruje, że po każdej wojnie pojawia się kolejna, co podkreśla traumatyczny aspekt naznaczenia, które zmusza do przygotowywania się na to, że historie, „którymi nas tuczono”, powrócą. To z tego powodu: „[...] / dziedziczna stała się / w nas ucieczka, ten podryg, / [...] / ten strach / [...] / ten nerw, który nagle się pobudza / i drży w oku, kiedy idzie noc, / [...]"7.

Tytuł tomu wierszy Tomasza Pietrzaka odsyła również do myślenia o uniwersalności oraz tragicznej powtarzalności wojny. Pospót to staropolska forma przysłówka „pospołu”, co znaczy „w tym samym miejscu oraz czasie”. W tym

2 Zob. T. Pietrzak: Stany skupienia. Brzeg 2008; TenżE: Rekordy. Nowa Ruda 2012; TenżE: Umlauty. Szczecin-Bezrzecze 2014; Tenże: Pospót. Mikołów 2016. Za tomy Umlauty oraz Rekordy poeta był nominowany do Nagrody Literackiej Nike.

${ }^{3}$ Pisownia oryginalna.

4 T. Pietrzak: Luzowanie. W: Tenże: Pospół..., s. 24.

${ }^{5}$ Tamże.

6 Tamże.

7 T. Pietrzak: Nerw. W: Tenże: Pospół..., s. 8.

${ }^{8}$ Hasło pospołu w: Słownik języka polskiego PWN. Dostępne w Internecie: https://sjp.pwn.pl/ sjp/pospolu;2505809.html [data dostępu: 24.02.2019]. 
kontekście nazwę tę można odczytywać jako określenie dokonującej się w czasie pewnej formy cyrkulacji i przekształcania się śladów wojny w pamięci kolejnych pokoleń. W lirykach pojawia się przekonanie, że z czasem Zagłada może utracić przypisywaną jej rangę najważniejszego oraz najtragiczniejszego wydarzenia w dziejach, ponieważ może zostać w przyszłości zastąpiona przez kolejny historyczny kataklizm. Przekazywane przez przodków opowieści, które stały się częścią podmiotu, zostaną zapomniane, a sytuacja krańcowa, do jakiej nawiązywały, będzie postrzegana jako jedna $\mathrm{z}$ wielu zaistniałych. W związku z tym w wierszach dostrzec można ponawiane próby zapisania pracy pamięci, pokazujące także kolejne etapy jej przekształcania się w wyobraźni jednostki.

\section{„W pewne wsie się nie wraca / mieszkają tam zimne diabły - / małe ruski"9 - Zagłada jako klechda}

Mierzenie się z przeszłością w twórczości Pietrzaka wymaga przywołania zasłyszanych historii, które podmiot utworów zna „[...] / z czyjejś obolałej pamięci i słów / [...]”10. Minione musi zostać wyrażone, ponieważ: „Milczenie nie jest złotem, jest wstydem. / Od milczenia gardło boli i stawy puchną / [...]"11. Niewypowiedziana historia pęcznieje i osadza się na kolejnych pokoleniach. To jednocześnie forma „zmagań między mówieniem a milczeniem, między nadmiarem języka a jego radykalną redukcją"12, charakterystyczna dla postholokaustowych relacji. W przypadku tomu Pospół próba eksplikacji osobistego naznaczenia zaczyna się od wpisania go w formę klechdy ${ }^{13}$. Rozpoczęcie tomiku wierszem o tym właśnie tytule sprawia, że zostaje zaznaczony czas, który minął

9 T. Pietrzak: Prowody. W: Tenże: Pospół..., s. 9.

10 T. Pietrzak: Klechdy. W: Tenże: Pospół..., s. 5.

11 T. Pietrzak: Causa mortis. W: Tenże: Pospół..., s. 20.

12 M. JANion: „Jeśli mówię o czymś na pozór całkiem innym, to i tak mówię o Auschwitz”. W: TAŻ: Bohater, spisek, śmierć. Wykłady żydowskie. Warszawa 2008, s. 279.

13 Autorzy Słownika terminów literackich podkreślają, że klechda związana jest „z lokalnymi tradycjami kulturalnymi, wierzeniami i obyczajowością danego regionu [...]”. To podanie „opowiadające [m.in. - M.D.] o niezwykłych wydarzeniach i osobliwościach krajobrazu”. Ponadto wskazują na pokrewieństwo z baśnią, „z którą łączą ją wspólne motywy i schematy tematyczne [...]” (Słownik terminów literackich. Red. J. SŁAw Iński. Wrocław 2002, s. 244-245). Natomiast Anita Jarzyna zwraca uwagę na etymologię tego słowa: „[...] oznaczała »klechda“ 'stare podanie ludowe, baśń'. W tej formie wyraz wprowadził do polszczyzny Tadeusz Czacki; pochodzi on od słów: »klekta«, »klechta«, czyli »plotka, bzdura«" (A. JARzynA: Imaginauci. Pismo wyobraźni w poezji Bolesława Leśmiana, Józefa Czechowicza, Krzysztofa Kamila Baczyńskiego, Tadeusza Nowaka. Łódź-Kraków 2017, s. 64). 
od tamtego wydarzenia, a także podkreśla się naturalny dystans wytworzony między podmiotem a przytaczanymi dramatycznymi historiami: „Teraz to już tylko latopis, / dopodusznik i śmierć w czytance, / żadna groza czasów, topór / nad głową"14. Okazuje się, że przeszłość, naznaczając podmiot, została jednocześnie wpisana $\mathrm{w}$ imaginacyjny porządek. Obecnie dramat rozgrywa się między innymi na kartach tzw. latopisu, czyli kroniki. Wydarzenie stało się również częścią klechdy, którą można opowiedzieć dziecku. Natomiast użycie neologizmu „dopodusznik" wzmacnia wyobraźniową formę opowieści. Świat przodków podmiotu został poddany narracji: „[...] / wszystko zostało spisane / [...]”15, dlatego „[...] / pora zapomnieć / [...]”16. Wykorzystanie baśniowej konwencji daje szansę na zbudowanie dystansu do przekazanej traumatycznej przeszłości. Umożliwia mierzenie się z ciężarem pamięci dzięki sprowadzeniu jej przedmiotu do na poły legendarnego wydarzenia, które nie powinno afektywnie wpływać na kolejne pokolenia. Wszak pamięć o sytuacji granicznej ulega stopniowym przekształceniom. Podmiotowi jawi się ona jako „[...] / - było, minęło, / a dla mojego syna tylko minęło / [..."”17. Opisywany świat obaj bohaterowie wiersza postrzegają z perspektywy powstałej w wyniku korelacji z pamięcią świadków, która została przekazana ojcu. Stąd też warte podkreślenia jest rozpoznanie, że: „[...] / Stoimy obaj na drugim brzegu / [...]"18. Nie powoduje to jednakże całkowitej zmiany perspektywy. Podmiot utworu niejako ukierunkowuje się na wydarzenie, jakie zostało mu przypisane, lecz „[...] / wystrzałów dawno nie słychać, / ani głosów, które im wtórowały, / ani wtórowania / [...]"19. Wobec tego przeszłość staje się historią i żadna opowieść nie jest w stanie jej urealnić, wręcz przeciwnie, zostaje odsłonięta jako niewyrażalna - „słodka klechda” ${ }^{20}$, której głównymi bohaterami stają się ludzie - potwory.

W wariancie baśniowym opowieści istotną rolę odgrywa figura „Rusa”. $\mathrm{W}$ wierszach okazuje się on postacią symboliczną, nawiązującą do wojennych działań Rosjan, takich jak gwałty, rubieże czy morderstwa, których pokłosiem są współczesne relacje polsko-rosyjskie. W utworze Pozostałostka podmiot powtarza niczym mantrę nauki babki: „Rusa trzeba nienawidzić / jak szczura, jest gorszy od Niemca; / Rus ze szklanek wydrapie złoto, / Rus z oczu wydrapie łzy - / [...]"21. Słowa babki są pogłosem jej traumatycznych przeżyć wojennych. Kobieta została „Z wielu narodów ulepiona / i jak sojusz rozpadła się -"22. Jej

\footnotetext{
14 T. Pietrzak: Klechdy..., s. 5.

15 Tamże.

16 Tamże.

17 Tamże.

18 Tamże.

19 Tamże.

20 Tamże.

${ }^{21}$ T. Pietrzak: Pozostałostka. W: Tenże: Pospół..., s. 6.

22 Tamże.
} 
tragiczne doświadczenie, powód niesłabnącej nienawiści, okazuje się częścią cielesnej pamięci związanej z aktem gwałtu. Mimo upływu lat kobieta nadal nosi ciężar przeszłości w sobie: „[...] / Dla kobiety [...] / nawet jeden sołdat to nadmiar, / który załamuje / A ją gniótł / aż sześćdziesiąt trzy lata / [...]"23. Historia babki ulega tabuizacji. Nie może jednak zostać zapomniana, ponieważ częścią tamtego wydarzenia stało się dziecko - ironicznie nazwane „pozostałostką” - które nieprzerwanie przywołuje traumatyczną przeszłość: „[...] / o tym się milczało, siedząc / nad okaleczonymi szklankami / i z dzieckiem, które jej zostało, / [...]"24.

Przedstawione w wierszu tragiczne zdarzenie przyjmuje charakter niewyobrażalnej opowieści, w której Rus otrzymuje rolę diabła. Analogiczny motyw pojawia się w utworze Nerw, w którym powtarzane przez matkę zapewnienie, „[...] / że jak Rus wejdzie, / to ona rzuci się z okna / [...]"25, zostaje narracyjnie uzasadnione pojawieniem się w przeszłości tajemniczych postaci, destabilizujących rzeczywistość: „[...] / Ulicami kręcili się wtedy / tacy, co całusem łamali gnaty / i jak mamuny siali dzieci / [..." ${ }^{26}$. Folklorystyczny kontekst wywołuje potrzebę konkretyzacji ludzkiego strachu. Podmiot wiersza, nie będąc świadkiem zdarzeń, stara się przybliżyć i jednocześnie zrozumieć przeszłość przodków. Postanawia zatem wpisać minione w system wierzeń, w których wspomniani „Ruscy” stają się wyobrażeniowymi postaciami - „mamonami”, pojawiającymi się - według przekonań ludu - „w nocy na polach, mokradłach i w lasach” 27. Wodziły one ludzi po bezdrożach, czasem całą noc. Takie przedstawienie wroga to nie tylko próba oswojenia tragicznej przeszłości, ale także efekt przekształcania się historii w system współczesnych wierzeń. Carl Gustav Jung twierdzi, że „każda epoka tworzy własne obrazy lęku”28. Fantazmatyczne postaci w poezji Pietrzaka są dowodem na ewoluowanie wspomnień, ponieważ „wierzenia [...] zostały stworzone przez człowieka głównie po to, aby mógł on zwalczyć swój lęk” "29. Stąd też w innym wierszu pojawia się przesądne przekonanie, że „W pewne wsie się nie wraca, / mieszkają tam zimne diabły - / małe ruski / [...]"30.

Istnieje zatem krajobraz, który uległ skażeniu za sprawą dramatycznych wydarzeń. Stał się obszarem zamieszkałym wyłącznie przez dzieci diabłów, które „[...] / po wojnie wypełzły z bab / [...]”31. Wymowa tragicznej klechdy

23 Tamże.

24 Tamże.

25 T. Pietrzak: Nerw..., s. 8.

26 Tamże.

27 D. Simonides: Wierzenia i zachowania przesądne. W: Folklor Górnego Śląska. Red. D. SiMONIDES. Katowice 1989, s. 253.

28 Cyt. za: tamże, s. 233.

29 Tamże, s. 232, 233.

30 T. Pietrzak: Prowody..., s. 9.

31 Tamże. 
ulega intensyfikacji dzięki wykorzystaniu imaginacyjnych wątków. Warto podkreślić też, że nie wszystkie "małe ruski”"32 miały szansę się narodzić, niejednokrotnie matki nie chciały wydawać ich na świat. W tej sytuacji krajobraz uległ całkowitej zmianie, od tamtej pory przechowuje te niechciane istoty, które „[...] / przeszastała rzeka” ${ }^{33}$. Wybór określonej przestrzeni na dokonanie zabójstwa nie jest gestem przypadkowym. Martin Pollack w książce Skażone krajobrazy zauważa, że dokonane mordy „mają stać się niewidoczne dla postronnych, zatopić w krajobrazie, być nim”34, by „pogrzebane [...] ciała zniknęły”35. Okazuje się jednak, że to właśnie przestrzeń odkrywa ślady, które nie pozwalają zapomnieć o przeszłości: „[...] / To dlatego kamienie jak nagie / brzuchy wystają ponad wodę / [...]"36.

\section{„Nie wszystek umiera - i ty masz w sobie dziada złego"37 Dziady i Zagłada}

Intensywna współzależność wydarzenia krańcowego oraz porządku przyrody kieruje wyobraźnię autora Pospołu w stronę obrzędu dziadów. Jego celem byłoby szczególnego rodzaju przywołanie zmarłych, by oswoić i zrozumieć przeszłość, która stała się również udziałem podmiotu. Odtwarzanie ludowego rytuału wynika także z pragnienia uzyskania spokoju zarówno przez żywych, jak i zmarłych. W wierszu otwierającym cykl, zatytułowanym Dziady, ujawnia się kluczowa dla obrzędu postać dziadka. Mężczyzna zdaje się zawieszony między dwoma światami: żywych oraz zmarłych. Doświadczenie wojny pozwoliło mu doznać wtajemniczenia, niedostępnego dla potomka. W utworze $Z$ wid szczególnego rodzaju zdolności adaptacyjne dziadka sprawiły, że został naznaczony, wówczas gdy głód doprowadził do destabilizacji znanego porząaku: „Doszło do tego, / że ludzie bali się zwierząt, / które sami udomowili. / Głód wziął obie strony po równo / i jednako ścisnął gardła / [... ${ }^{338}$. Wtedy też dokonała się inicjacyjna transpozycja w życiu mężczyzny, która sprawiła, że: „[...] / Mój dziadek / [...] / spał, kundle jadł / To dlatego, / żaden mu nie podskoczył, / to dlatego tak / potulniały przy nim leśne oczy / [...]"39. W pewnym sensie starszy mężczyzna w wyniku wojennych doświadczeń otrzymał władzę nad florą i fauną.

\footnotetext{
32 Tamże.

33 Tamże.

34 M. Pollack: Skażone krajobrazy. Przeł. K. Niedenthal. Wołowiec 2014, s. 20.

35 Tamże.

36 T. Pietrzak: Prowody..., s. 9.

37 T. Pietrzak: Cząstka elementarna. W: Tenże: Pospół..., s. 14.

38 T. Pietrzak: Zwid. W: Tenże: Pospół..., s. 10.

39 Tamże.
} 
Dziadek może kojarzyć się z Guślarzem - cadykiem. Katarzyna Kornacka-Sareło w książce Motywy kabalistyczno-frankistowskie w „Dziadach” Adama Mickiewicza interpretuje wspomnianą Mickiewiczowską postać jako „odpowiednik cadyka, przywódcy ludowego, który we wszystkich wspólnotach chasydzkich łączył »ziemię« $\mathrm{z}$ »niebem«, świat żyjących ze światem zmarłych, poczuwał się do odpowiedzialności za wszystkich członków swojej wspólnoty [...]"40. W wierszach Pietrzaka dziadek staje się jedyną osobą, która jest w stanie nawiązać kontakt ze zmarłymi i prowadzić z nimi dialog. Jego wnuk bierze natomiast udział w obrzędzie jako spektator, który jednak pragnie stać się jego częścią: „[...] / Pytałem go wczoraj / a on zrobił unik jak w okopie / i rozmawiał ze zmarłymi, / przedstawiał nas sobie / [...]"41.

Głównym powodem, dla którego osoba mówiąca w utworze dąży do poznania tajemnicy zaświatów, staje się postępujące zamykanie się dziadka wewnątrz świata duchów. Guślarz - cadyk w istocie nie wspiera dusz zmarłych w dążeniu do osiągnięcia stanu odkupienia. Mężczyzna pozostaje wśród zmarłych pomimo nakarmienia duchów, co sugerowałoby spełnienie ich prośby: „[...] / - i trzeba było podać obiad, / nie dla dwóch, a dla hurmy / [...]"42. Niemniej dziadek nie przestaje przywoływać pozornie minionego, z którego jako świadek nie potrafi zrezygnować. Dlatego niewypełnienie obrzędu powoduje, że kolejnego dnia Guślarz: „[...] / nasłuchuje / ryku z radia, widzi go w pralce, / wsłuchuje się jak mieli głos, / a w przerwach gra mu marsz / [...]"43. Mężczyzna poszukuje kolejnych znaków świadczących o przebywaniu zmarłych w teraźniejszości. Wobec tego Zeyde jako osoba do końca swojego życia odpowiedzialna za duchy nie godzi się na ostateczne zerwanie z przeszłością. Jego decyzja prowadzi do tragicznych skutków. Śmierć Guślarza okazuje się tożsama z przejęciem przez wnuka ciężaru pamięci oraz odpowiedzialności za zmarłych: „Zaraz po śmierci / nie ma się czasu na łzy, / jest ciężka robota / i dość szybko opada się / z sił. A to dopiero doba / z osiemdziesięciu lat / do wyniesienia / [...]"44. Wcześniejsza rola obserwatora została przekształcona w powiernika. Tym razem obecność cudzych wspomnień sprawia, że osoba mówiąca w wierszu dąży do zerwania z naddaną przeszłością: „[...] / Zbyt cudze jest to życie / i niczyje wspomnienia / [..." "45. Decyzja o ich odrzuceniu nie jest jednak możliwa ze względu na to, że podmiot nie stał się następcą Guślarza. Otrzymał w spadku minione, lecz bez obrzędowego wtajemniczenia. Nie może dopełnić dziadów, ponieważ nie jest ich mistyczną częścią. Podmiot podkreśla ustawiczne uwikłanie, pozbawione

${ }^{40}$ K. Kornacka-Sare€o: Motywy kabalistyczno-frankistowskie w „Dziadach” Adama Mickiewicza. Poznań 2016, s. 59.

${ }^{41}$ T. Pietrzak: Teufelslied. W: Tenże: Pospót..., s. 12.

42 Tamże.

43 Tamże.

${ }^{44}$ T. Pietrzak: $W$. W: Tenże: Pospół..., s. 13.

${ }^{45}$ Tamże. 
możliwości zmiany: „[...] / Paktujemy więc ze śmiercią, / jeszcze przez chwilę podglądamy, / jak rośnie, jak wypełnia siebie / i świat, / [...] / który tak na nas zaciąży ${ }^{\prime 46}$. W takim kontekście intryguje także uwypuklenie tego składnika ludzkiej egzystencji, który sprawia, że to, co zostało przekazane, trwa nieustannie. W wierszu Czastka elementarna podmiot wskazuje, że owo trwanie wynika z korelacji świata żywych i zmarłych:

Nie wszystek umiera - i ty masz w sobie dziada złego,

dziad śpi w tobie, głodnieje, pije na umór $[\ldots]$

Bywa, że odbiera ci usta, - mówi; przejmuje ręce wzrok, widzi świat za ciebie; i ty widzisz jak dziad zły w czerni i bieli, w żalu i nieustannej goryczy $[\ldots]^{47}$

Okazuje się, że przejęcie wspomnień wiąże się z jednoczesnym zespoleniem z duszą zmarłego. Ową tytułową „cząstką elementarną” staje się postać złego dziada, która dzięki głębokiemu wpływowi na jednostkę - tożsamemu z przejęciem jej życia - przypomina dybuka. Dybuk to dusza potępiona, naga, tułająca się, błądząca ${ }^{48}$. To duch, który „nie chce odejść, ponieważ jedyną możliwością jego trwania oraz subiektywnego poczucia, że jeszcze istnieje, jest przejęcie w swoje władanie ciała osoby żyjącej. Staje się ona wówczas sui generis medium łączącym świat żywych z dziedziną zmarłych" ${ }^{\prime 9}$. Ponadto sparafrazowana na początku utworu myśl Horacego: „I nie wszystek umrę”, zaznacza silny związek przemawiającego dybuka $z$ opętanym podmiotem. Władzę ducha nad osobą mówiącą w wierszu można symbolicznie odczytywać jako formę nieodwracalnego oraz trwałego przywiązania do przeszłości. Kluczowy aspekt owego mistycznego przylgnięcia ujawnia się w kolejnych wersach: „,...] / Nie wyplenią go zamoczki, / ani koronki, nie wytrzebi go / święta nawijka i odmawiajka. / [...]" ${ }^{50}$. Obrzęd, którego podmiot był niegdyś świadkiem, jawi się wobec działania dybuka jako niewystarczający. Zostaje niejako pozbawiony atrybutu wiary, dlatego dziady

46 Tamże.

47 T. Pietrzak: Czastka elementarna..., s. 14.

48 G. Scholem: Kabbalah. New York 1987, cyt. za: K. Kornacka-SareŁo: Motywy kabalistyczno-frankistowskie w „Dziadach” Adama Mickiewicza..., s. 67.

49 Tamże, s. 68.

50 T. Pietrzak: Cząstka elementarna..., s. 14. 
są zastąpione nazwami: „nawijka”, „odmawiajka”, wyrażającymi dystans podmiotu. Jak zauważa Katarzyna Kornacka-Sareło, dybuk „stanowi rodzaj ducha totalnie zależnego od działań osób żyjących. To one są władne sprawić, dzięki odpowiednim zaklęciom i egzorcyzmom, iż błąkająca się dusza odnajdzie po śmierci pewien rodzaj spokoju" ${ }^{51}$. Jednak po śmierci dziadka-Guślarza potomek nie potrafi odesłać ducha i tym samym uwolnić się od jego wpływu. Dlatego wobec niemożliwości zmiany opisywany duch zaczyna jawić się jako wpisane w egzystencję jednostki „drzemidło”: „[...] / Żaden to duch, to drzemidło, / białko scalające, pospół genu, / co nieustannie wodzi za nos / i nie odciąga ode złego" ${ }^{2}$. Staje się zatem postacią, która nie tylko panuje nad człowiekiem, ale, co więcej, niejako wchodzi w materię podmiotu. Tragiczne wspomnienia jednostki można więc postrzegać jako dręczącego ją dybuka, którego obecność w ostateczności zmusza do nieprzerwanego odpominania minionego. Także słowo „pospół” oznaczałoby w tym kontekście pewne wspólnotowe doświadczenie, wychodzące poza osobiste przeżycie. W perspektywie językowej połączenie przyimka „po”, sugerującego postpamięciowy charakter wspomnień, oraz „spół”, odsyłającego do genetycznej wspólnoty, podkreśla niezwykle silną więź, która została wytworzona między wnukiem a przekazaną przeszłością dziadka. W ich relacji dostrzec można wpływ transgeneracyjnej „pamięci genów”. Anna Artwińska w artykule Transfer międzypokoleniowy, epigenetyka i "więzy krwi”: o „Małej Zagładzie” Anny Janko i „Granicy zapomnienia” Siergieja Lebiediewa zauważa, że ów biologiczny transfer to „wizja tożsamości, która kształtuje się bez naszej woli i wiedzy; dlatego więź międzypokoleniowa nie jest aktem wyboru lecz koniecznością - losy jednego pokolenia determinują losy pokoleń po nim następujących" ${ }^{53}$. Z tego względu mierzenie się wnuka z przeszłością przodka staje się formą przeżywania minionego $\mathrm{w}$ perspektywie wydarzenia postkatastroficznego, w którym kategoria czasu „jest czymś wielowarstwowym, złożonym z różnych, nakładających się na siebie i wchodzących z sobą w różne interakcje warstw" ${ }^{\prime 4}$.

${ }^{51}$ K. Kornacka-Sarezo: Motywy kabalistyczno-frankistowskie w „Dziadach” Adama Mickiewicza..., s. 68.

52 T. Pietrzak: Czastka elementarna..., s. 14.

53 A. Artwińska: Transfer międzypokoleniowy, epigenetyka i „więzy krwi”: o „Małej Zagładzie” Anny Janko i „Granicy zapomnienia” Siergieja Lebiediewa. „Teksty Drugie” 2016, nr 1, s. 21. Artwińska w perspektywie genealogicznej przywołuje biologiczne tłumaczenie „pamięci genów”: „[...] oprócz informacji zawartych w genotypie komórki człowieka przechowuje się także inne informacje [...] o swojej prehistorii. Za przekaz tych informacji odpowiedzialny jest tzw. kod epigenetyczny [...]. Tym samym oprócz łańcucha nici DNA w organizmie człowieka istnieje także inny biologiczny system informacyjny, któremu komórki zawdzięczają wiedzę o swojej przeszłości” (tamże, s. 19).

${ }^{54}$ A. Artwińska: „Odrodziły się traumy z czasów Zagłady”. Marzec 1968 jako narracja postkatastroficzna. „Poznańskie Studia Polonistyczne. Seria Literacka” 2015, nr 25, s. 188. 


\section{„Grzeb w ziemi, grzeb ${ }^{55}$, więcej prawdy wyjdzie w twoim pokoleniu”56 Zagłada jako (pozo)stałość}

O ile w planie więzi pokoleniowych istotna jest perspektywa genetyczna, o tyle w planie wyobraźni poetyckiej ważna okazuje się perspektywa środowiskowa i geo$\operatorname{logiczna}{ }^{57}$. Wojna w kolejnych wierszach nie wpisuje się już w baśniowy porządek, natomiast odtwarzanie przeszłości dokonuje się przez ukierunkowanie na krajobraz, który gromadzi w sobie pozostałości utraconego świata. Pojawia się zatem zwrot ku szczątkom ludzkim, przechowywanym nadal przez ziemię. Szczególną uwagę zwracają kości, które wraz z upływem czasu zaczynają być postrzegane jako odnalezione artefakty obcej cywilizacji: „Co masz w piąstce? / To chrząstka z wojny, / a to kostka po koniu / [...] / Prawdziwe piekło / drzemie płytko / [...]"58. Okazuje się, że tego typu pozostałości Zagłady, związane z określoną przestrzenią, nie tylko przyczyniają się do odtwarzania przeszłości, ale również uwypuklają zmianę perspektywy. Podmiot poprzez kontakt z naznaczonym obszarem dochodzi do podobnego wniosku jak Martin Jay, że „krajobraz jest medium, poprzez które zło jest ukrywane i naturalizowane" ${ }^{59}$. Stąd też postrzeganie osoby mówiącej w wierszu wiąże się ze świadomością uczestniczenia w pewnym procesie dziejo-

55 Formułę „grzebania” przywołuje także Marta Baron w kontekście twórczości Jerzego Ficowskiego. Dla autorki, podobnie jak jest to w poezji Pietrzaka, grzebanie to metafora „pragnienia odkrycia sensu czy tajemnicy [...]; odkopywania, które stale nieskuteczne, zakopuje coraz głębiej; odkrywania nierozłącznego z zakrywaniem [...]” (M. BAron: Grzebanie grzebania. Archeolog i grabarz w twórczości Jerzego Ficowskiego. Katowice 2014, s. 15).

56 T. Pietrzak: Fafel. W: Tenże: Pospół..., s. 15.

$57 \mathrm{~W}$ badaniach nad Zagładą w perspektywie geologicznej (łączącej się ze środowiskową) zwraca się uwagę na „relacje zachodzące w środowisku między czynnikami ludzkimi a nie-ludzkimi (np. roślinami, zwierzętami, klimatem, pogodą, ukształtowaniem terenu, zarazkami itd.). Po pierwsze, zajmuje się ona wpływem środowiska na przebieg Zagłady (na przykład znaczeniem warunków naturalnych w lokalizowaniu oraz funkcjonowaniu obozów, wpływem klimatu i pogody na życie więźniów w obozach i gettach, wykorzystywaniem przyrody jako narzędzia zbrodni). Po drugie, bada wpływ Zagłady na środowisko (na przykład skutki funkcjonowania obozów i gett [...]). Po trzecie, interesuje się rozmaitymi wyobrażeniami, znaczeniami i wartościami związanymi z przyrodą w kontekście Zagłady (na przykład sposobami przedstawiania przyrody w relacjach ocalałych, rolą krajobrazu w imperialnej polityce Trzeciej Rzeczy [...])" (J. MaŁczyński: Krajobraz Zagłady. Perspektywa historii środowiskowej. Warszawa 2018, s. 9). Zob. także: A. Ubertowska: Natura u kresu (ekocyd). Podmiotowość po katastrofie. „Teksty Drugie” 2013, nr 1-2, s. 35 oraz T. Cole: Lasy, drzewa i historie środowiskowe Holokaustu. Przeł. K. Dix. „Teksty Drugie” 2017, nr 2, s. 203-226.

58 T. Pietrzak: Fafel..., s. 15.

${ }_{59}$ M. Jay: No State of Grace. Violence in the Garden. Przeł. J. MaŁczyński, cyt. za: J. MaŁCZYŃsKi: Krajobrazy Zagłady..., s. 83. 
wym. Poszukiwanie kości ${ }^{60}$ jest próbą wytworzenia dystansu wobec tragicznego wydarzenia, ale jednocześnie ma na celu pokazanie uniwersalności wojny, która nigdy się nie kończy. Dlatego podmiot w utworze Luzowanie stwierdza: „Nim przyjdzie nowa wojna / pozbądźmy się resztek starej / [...]"61.

Z jednej strony zauważyć można, że odkryte szczątki ludzkiego ciała odsyłają do refleksji z opowiadania U nas $w$ Auschwitzu Tadeusza Borowskiego. Realizacja nazistowskiej utopii zostaje przez pisarza włączona w schemat jednej z wielu katastrof cywilizacyjnych, które doprowadziły do masowych śmierci:

[...] Zakładamy podwaliny jakiejś nowej, potwornej cywilizacji. Teraz dopiero poznałem cenę starożytności. Jaką potworną zbrodnią są piramidy egipskie, świątynie i greckie posągi! Ile krwi musiało spłynąć na rzymskie drogi, wały graniczne i budowle Miasta! Ta starożytność, która była olbrzymim koncentracyjnym obozem, gdzie niewolnikowi wypalano znak własności na czole i krzyżowano za ucieczkę. Ta starożytność, która była wielką zmową ludzi wolnych przeciw niewolnikom ${ }^{62}$.

W tym kontekście także dla podmiotu Pietrzaka opisywane wojenne „odkrycia" stają się tragiczną częścią minionej cywilizacji, po której nieuchronnie pojawią się kolejne. Dlatego w wierszu Lokatorzy podkreśla, że „[...] / Przechodni jest świat / i ziemia bez ustanku przesypuje się / [...]"63, zaznaczając po raz kolejny dramatyczną cykliczność wydarzeń o charakterze krańcowym. Z drugiej strony w poezji zostaje uwypuklone owo nastawienie na na poły archeologiczny szczegół, otrzymujący status odhumanizowanego przedmiotu, z którym jednakże podmiot znajduje się w ustawicznej relacji:

Torba żeber wisi w piwnicy

i garść garści leży w bratkach.

Nawet teraz, gdy rwę chwasty

Zdarza mi się wpaść w oczodół,

A kiedy leżę w ogrodzie, leżymy

Razem w rozmemłaniu światów ${ }^{64}$.

${ }^{60}$ Ewa Domańska zwraca uwagę na dokonujące się społeczne zdystansowanie od szczątków, które z czasem zaczynają być postrzegane jako kryminalne dowody. „Owa normalizacja [...] martwego ciała [...] zredukowała jego ontologiczny status do rzeczy, do corpus delicti (przedmiotu przestępstwa) właśnie”. W tym kontekście ujawnia się także proces przekształcania się pamięci o miejscu masowych zbrodni, które w ostateczności „[...] stanowią wypadkową różnych przenikających się procesów zarówno społeczno-politycznych i kulturowych, jak i biologicznych, klimatycznych i geologicznych" (E. Domańska: Nekros. Wprowadzenie do ontologii martwego ciała. Warszawa 2018, s. 181, 204).

${ }^{61}$ T. Pietrzak: Luzowanie..., s. 24.

${ }^{62}$ T. Borowski: U nas w Auschwitzu. W: Tenże: Utwory wybrane. Oprac. A. Werner. Wrocław-Warszawa-Kraków 1991, s. 109.

${ }^{63}$ T. Pietrzak: Lokatorzy. W: Tenże: Pospót..., s. 25.

${ }^{64}$ T. Pietrzak: Posesja. W: Tenże: Pospół..., s. 23. 
Okazuje się, że owo nieustanne mieszanie się wspomnianych śladów cywilizacji nie prowadzi do całkowitego zapomnienia przeszłości. Przeciwnie, przestrzeń staje się niejako naturalnym strażnikiem, przechowującym między innymi fizyczne znaki minionego. Podobna wizja krajobrazu pojawia się także w wierszu Krzysztofa Kamila Baczyńskiego Historia. Również tam przestrzeń znajduje się w trwałej korelacji z wojną. Jest nieustannym miejscem bitwy odsyłającym do zgiełku wojny. Janusz Sławiński w interpretacji wiersza Baczyńskiego zauważa, że wizyjność utworu „nie prowadzi do odczytania w świecie danym zapowiedzi przyszłości, lecz przeciwnie - odkrywa w nim życie przeszłości” ${ }^{\prime}$. Co więcej, to widzenie, jak kontynuuje Sławiński, „reinterpretuje zastany krajobraz, wyzwalając z niego dynamikę zdarzeń i działań, oswobadzając zamknięte w nim wspomnienie historii”"66. Wobec tego „Pejzaż nie zapomina”, ${ }^{67}$, ale też zmusza do ciągłego zadawania pytań, takich jak te, które mnoży Martin Pollack: „Czy ten krajobraz coś przed nami skrywa? Czy rzeczywiście jest taki niewinny, idylliczny, jak się pozornie wydaje? Co znajdziemy, jeśli zaczniemy tu kopać? Czy ukażą się nam wtedy zbutwiałe kości? Czy mamy je wtedy odłożyć obojętnie na bok, ponieważ rzekomo wcale nas to nie dotyczy, bo z tym, co się tu działo, nie mamy nic wspólnego?" ${ }^{38}$.

W poezji Pietrzaka uosobione drzewa nieomal oczekują na odkrycie pozwalające znaleźć odpowiedź na postawione pytania. Wykonują wobec tego szereg ludzkich gestów: „[...] / te stare dębiska w kącie posesji / mają posturę, a gąszcz sylwetkę, / nawet jesiony kiwają się ludzko / i pochylone wierzby płaczą coś / do kwaśnego jeziora / [...]" $]^{p 9}$. Przyroda, przyjmując antropomorficzną formę, jednocześnie współodczuwa, co pokazuje dokonane zespolenie obszaru i świadków przeszłej cywilizacji. Równocześnie, obok przestrzennej perspektywy, ukazującej trwałość istnienia opisywanych śladów, pojawia się także przekonanie, że każdy odkryty fragment należący do przeszłości uzyska z czasem charakter eksponatu. Ten etap przekształcania pamięci okazuje się ostatnim przed nastaniem kolejnej wojny:

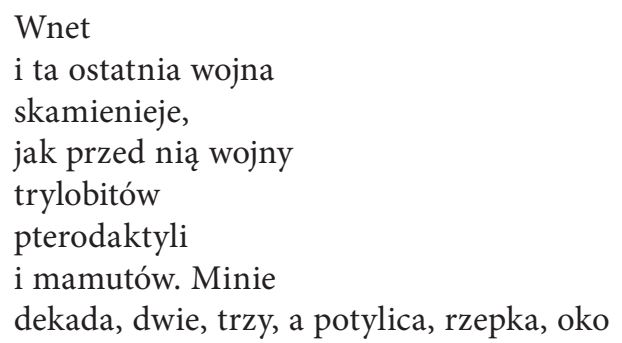

${ }^{65}$ J. SŁAWIŃski: Krzysztof Kamil Baczyński: „Historia”. W: Liryka polska. Interpretacje. Red. J. Prokop, J. SŁaWiński. Gdańsk 2002, s. 433.

66 Tamże.

67 T. Pietrzak: Posesja..., s. 23.

${ }_{68}^{6}$ M. Pollack: Skażone krajobrazy..., s. 54.

${ }^{69}$ T. Pietrzak: Posesja..., s. 23. 


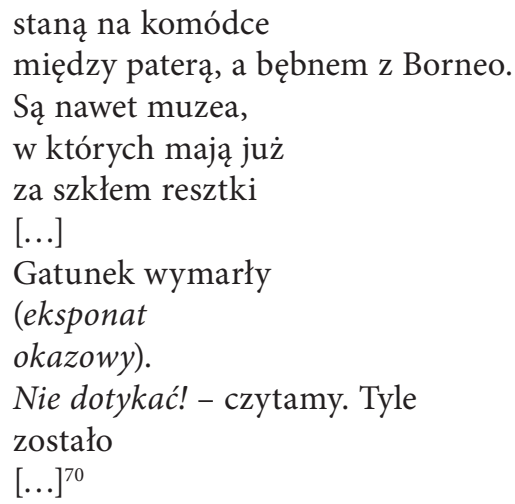

Elementy przeszłości staną się z czasem szeregiem zamkniętych w gablocie rzeczy pozbawionych afektywnego odniesienia ${ }^{71}$. Pietrzak w swych wierszach pokazuje, w jaki sposób pamięć ulega przekształceniu w cyklu historycznym. W tomie Pospót ten proces rozpoczyna się od wpisywania minionego w klechdę, która funkcjonuje zarówno jako forma oswojenia, jak i uniezwyklania niewyobrażalnego wydarzenia. Kolejny etap związany z materialnym aspektem życia dotyczy rejestru archeologicznych odkryć i ma na celu uwypuklenie nieuchronności oraz niesamowitości przeszłego świata. „Ostatnia wojna”, podobnie jak zagłada dinozaurów, podlega schematowi ponawianego doświadczenia. Dostrzeżone etapy mogą być interpretowane w kontekście wspomnianej na początku zmazy, charakteryzowanej przez Barbarę Skargę. Badaczka zauważa, że owo naznaczenie byłoby tożsame $\mathrm{z}$ pewnego rodzaju nieczystością, skalaniem czymś, co wymaga oczyszczenia. Zapisywanie, wynikające z próby radzenia sobie z ciężarem pamięci, można zatem odczytywać jako rodzaj rytuału, w którego wyniku podmiot mógłby zostać uwolniony od tego naznaczenia ${ }^{72}$. Jednak utwór o znamiennym tytule Prolog nie pozostawia złudzeń, że możliwe jest zerwanie z tragicznym, powtarzającym się schematem. Przeciwnie, ponawiane odrodzenie świata realizuje się wyłącznie po to, by przygotować się na kolejną wojnę, mimo że „Ledwo co nam nogi wyrosły, / a już rwiemy się by je wyrwać, / ledwo co ręce zaczęły chwytać, / a już wolą wypuszczać świat. / A ten wiruje, jak wieki wirował / [...]"73.

70 T. Pietrzak: Wyrzut. W: Tenże: Pospół..., s. 27.

${ }^{71} \mathrm{O}$ muzealizacji Zagłady pisała m.in. Iwona Kurz: „Odnalezione w lesie resztki nie mają już, co oczywiste, żadnej wartości użytkowej. Ich wartość symboliczna i pamiątkowa również jednak, jak się zdaje, uległa deprecjacji. [...] Czas, który upłynął od wojny, dokonał zniszczenia nie tylko samych obiektów, ale też ich symbolicznej, pamiątkowej aury” (I. Kurz: Buty. W: Ślady Holocaustu w imaginarium kultury polskiej. Red. J. Kowalska-Leder, P. Dobrosielski, I. Kurz, M. Szpakowska. Warszawa 2017, s. 73).

72 Zob. B. Skarga: Ślad i obecność..., s. 77.

73 T. Pietrzak: Prolog. W: Tenże: Pospół..., s. 32. 


\section{Bibliografia}

ARTwińsKa A.: „Odrodzity się traumy z czasów Zagłady”. Marzec 1968 jako narracja postkatastroficzna. „Poznańskie Studia Polonistyczne. Seria Literacka” 2015, nr 25, s. 187-208.

Artwińska A.: Transfer międzypokoleniowy, epigenetyka $i$ „więzy krwi”: o „Małej Zagładzie” Anny Janko i „Granicy zapomnienia” Siergieja Lebiediewa. „Teksty Drugie” 2016, nr 1, s. 13-29.

Baron M.: Grzebanie grzebania. Archeolog i grabarz w twórczości Jerzego Ficowskiego. Katowice 2014.

Borowski T.: U nas w Auschwitzu. W: T. Borowski: Utwory wybrane. Oprac. A. WerNER. Wrocław-Warszawa-Kraków 1991, s. 105-146.

Cole T.: Lasy, drzewa i historie środowiskowe Holocaustu. Przeł. K. Dix. „Teksty Drugie" 2017, nr 2, s. 203-226.

Domańska E.: Nekros. Wprowadzenie do ontologii martwego ciała. Warszawa 2018.

Folklor Górnego Śląska. Red. D. Simonides. Katowice 1989.

JANION M.: Bohater, spisek, śmierć. Wykłady żydowskie. Warszawa 2008.

Jarzyna A.: Imaginauci. Pismo wyobraźni w poezji Bolesława Leśmiana, Józefa Czechowicza, Krzysztofa Kamila Baczyńskiego, Tadeusza Nowaka. Łódź-Kraków 2017.

Kornacka-SareŁo K.: Motywy kabalistyczno-frankistowskie w „Dziadach” Adama Mickiewicza. Poznań 2016.

Kurz I.: Buty. W: Ślady Holocaustu w imaginarium kultury polskiej. Red. J. KowALsKA-Leder, P. Dobrosielski, I. Kurz, M. SzPakowska. Warszawa 2017, s. 57-80.

MaŁczyńsKi J.: Krajobrazy Zagłady. Perspektywa historii środowiskowej. Warszawa 2018.

Pietrzak T.: Pospót. Mikołów 2016.

Pietrzak T.: Rekordy. Nowa Ruda 2012.

Pietrzak T.: Stany skupienia. Brzeg 2008.

Pietrzak T.: Umlauty. Szczecin-Bezrzecze 2014.

Pollack M.: Skażone krajobrazy. Przeł. K. Niedenthal. Wołowiec 2014.

SkARGA B.: Ślad i obecność. Warszawa 2002.

SŁAWIŃsKi J.: Krzysztof Kamil Baczyński: „Historia”. W: Liryka polska. Interpretacje. Red. J. Рвокор, J. SŁAwiński. Gdańsk 2002, s. 428-440.

Słownik języka polskiego PWN. Dostępne w Internecie: https://sjp.pwn.pl/ [data dostępu: 24.02.2019].

Słownik terminów literackich. Red. J. SŁAwIŃsKI. Wrocław 2002.

Ubertowska A.: Natura u kresu (ekocyd). Podmiotowość po katastrofie. „Teksty Drugie” 2013, nr 1-2, s. 33-44. 
Martyna Dymon

"What if I do not believe in this war, just as I do not believe in dinosaurs? [...]" On the War after the War in Tomasz Pietrzak's Poetry

\section{Summary}

This article focuses on Tomasz Pietrzak's Pospót [The Common], which correlates the memory of the Shoah with Silesian tropes. The traces of tragic past - which still inhabits the reality are visible in on-going social and psychological conflicts, and in the attempts to integrate the memories that rely on the liminal events. As it is shown, the memory of the ultimate event is presented in Pietrzak's works as a process. Its first stage is concerned with inscribing the Shoah in a regional folk tale, making it possible to distance oneself from the traumatic yet already transmitted past. Furthermore, this variant relies on the interrelation between the ultimate event and nature. The poet refers to the Slavic fest of dziady, which not only brings the dead back to life in a very peculiar manner, but also encourages us to familiarise with and understand the past. The next stage places the Shoah in the environmental and geological contexts. Recalling the tragic past relies on the author's dependence on a landscape which accumulates the remnants preserved in the soil. In the course of its analysis, the article comments upon a "turn to museums" in re-thinking the Shoah, which is supposed to be the last transformation of memory, anticipating the outbreak of yet another war.

Key words: Tomasz Pietrzak, Holocaust, poetry, memory, Silesia 

Przekłady 
